\title{
Learn to Lead: Mapping Workplace Learning of School Leaders
}

\author{
Frank Arnoud Hulsbos ${ }^{1}$. \\ Arnoud Theodoor Evers ${ }^{1}$. \\ Joseph Willem Marie Kessels ${ }^{1}$
}

Received: 18 May 2015 / Accepted: 15 September 2015 /

Published online: 6 October 2015

C The Author(s) 2015. This article is published with open access at Springerlink.com

\begin{abstract}
In recent years policy makers' interest in the professional development of school leaders has grown considerably. Although we know some aspect of formal educational programs for school leaders, little is known about school leaders' incidental and non-formal learning in the workplace. This study aims to grasp what workplace learning activities school leaders value most, what work-related questions incite them to learn, what outcomes they achieve through workplace learning and what conditions support workplace learning of school leaders. In order to generate answers to the research questions, we conducted semi-structured interviews with 20 Dutch school leaders in secondary education, which also served as a form of reflection for the respondents. Results show that school leaders mostly value workplace learning through working on improvement and innovation and through reflection. In addition to outcomes for the school leader, working on improvement and innovation also leads to learning outcomes for teachers, and seems to provide opportunities for teachers to influence changes in the school. On the other hand, teachers take little or no part in reflection. Here, school leaders find peace and stability to reflect with fellow school leaders. If adjusted to a specific context, the methods used in this study might be transferred to other contexts, to study workplace learning of all kinds of leaders.
\end{abstract}

Keywords Workplace learning · Incidental learning $\cdot$ School leaders · Teacher professional development $\cdot$ Distributed leadership

Frank Arnoud Hulsbos

frank@frankhulsbos.nl

1 Welten Institute. Research Centre for Learning, Teaching and Technology, Open University of the Netherlands, Valkenburgerweg 177, 6419 AT Heerlen, The Netherlands 


\section{Introduction}

In recent years, policy makers' interest in the professional development of school leaders has grown considerably (e.g., Darling-Hammond et al. 2009; The Wallace Foundation 2012a). This growing interest is not surprising, since a large body of research shows the significance of school leadership for improving learning outcomes of students (Branch et al. 2013; Day et al. 2009; Gurr 2015). In order to support professional development of school leaders, governments put several measures in place, such as formal registration systems for participation in professional development activities (Hulsbos et al. 2014). These policy initiatives and research findings show that the school leader carries out a specific profession for which specific competences are required. School leaders have not necessarily followed mandatory training before commencing the job. Nevertheless, school leaders have presumably learned during work, which has enabled them to practice their profession. These workplace learning activities of school leaders are the main subject of our study.

This study is aimed at Dutch secondary school leaders. Compulsory secondary education in the Netherlands offers education at three main levels: pre-vocational education ("vmbo"), higher general continued education ("havo") and pre-academic education ("vwo"). Students are aged between 12 and 18 years. Most schools are united in cross-school foundations with a board of directors, to whom the school leader is accountable. In their schools most school leaders mainly conduct managerial duties. In rare cases school leaders additionally conduct teaching tasks.

Although we have some knowledge about what constitutes successful formal training programmes for school leaders (e.g., The Wallace Foundation 2012b), research on what constitutes and supports incidental and non-formal workplace learning of school leaders is scarce. This is even more striking given the amount of research into workplace learning of other workers, such as teachers (e.g., Evers et al. 2015), academic librarians (Engeström et al. 2013), and physicians (Van de Wiel and Van den Bossche 2013). Therefore, in this article we present a study that applies existing theoretical concepts and allows for finding new concepts and relationships inductively. Our study adds to existing literature in at least two ways. First of all, our study adds to one of the main recent research lines in workplace learning of studies that describe the nature of workplace learning (Tynjälä 2013). Since school leaders' workplace learning is largely unexplored, this study provides an important first glance, which can also form the basis for future (quantitative) research in this area. Secondly, we present a practice-based research method to study workplace learning of school leaders. This research method can be adjusted to study workplace learning of leaders in similar professions.

The following research questions guide our study:

1) What learning activities in the workplace do school leaders in secondary education value most?

2) What work-related questions incite school leaders to participate in these learning activities, what conditions and characteristics facilitate these workplace learning activities and what learning outcomes (i.e., competencies) do they achieve through these workplace learning activities? 
In the Netherlands, professional development of school leaders in primary education has received a great deal of policy makers' attention. For example, a registration system to map primary school leaders' professional development is in place. More recently attention for secondary school leaders' professional development has grown (e.g., Waslander et al. 2012), which was an important motive to conduct this study in this specific field.

\section{Theoretical Framework of School Leaders' Workplace Learning}

In a recent literature review Tynjälä (2013) presents a "3-P model” to study workplace learning. Tynjälä elaborates on a holistic model developed earlier in the context of school learning by Biggs (1999), and adjusted this model to fit the nature of workplace learning. Tynjälä's model is comprehensive in that it captures the relationships between different components of workplace learning, such as the context of learning, specific learning activities and learning outcomes. Workplace learning of school leaders is a largely unexplored research field. Therefore the holistic set-up of this model is particularly useful to clarify in depth the nature of school leaders' workplace learning. The three P's in the model stand for "presage", "process" and "product". Similar to Tynjälä's model, our theoretical framework is built up around four major building blocks: learning activities in the workplace (process), work-related questions that incite workplace learning (presage), learning outcomes of workplace learning (product) and conditions and characteristics that facilitate workplace learning (also presage). The next paragraphs describe these building blocks more in depth.

\section{Workplace Learning Activities of School Leaders}

Providing a comprehensive review on workplace learning is beyond the scope of this article. We refer interested readers to e.g., Tynjälä (2008; 2013), Billett (2009), Fenwick (2008a, b) and Dochy et al. (2011). Here we give a brief overview of literature into workplace learning relevant for our study and describe the definition we adopt.

The research on workplace learning has expanded rapidly since Marsick and Watkins (1990) showed how - in addition to formal education - the working environment provides a rich landscape for learning. Based on the work of Billett (2004), Tynjälä (2013) identifies three modes of workplace learning, which differ in the degree to which they are formalised:

- Incidental and informal learning: these are all learning activities that take place as a side effect of work. Marsick and Watkins (1990) label this type of workplace learning simply as incidental, which we adopt for this study.

- Intentional, but non-formal learning related to work, such as mentoring or intentionally reflecting on a working experience. We refer to this category as non-formal workplace learning,

- Formal on- and off-the-job training, such as trainings and courses.

This study incorporates mainly learning activities that can be characterised as incidental and non-formal. In our search for literature on workplace learning activities 
of school leaders, we did not find specific research. Therefore we conducted an additional literature search in the context of teacher professional development. Since this is a broad research field we restricted our search to well-known studies (Avalos 2011; Bakkenes et al. 2010; Benson 2010; Evers 2012; Fazio 2009; Kwakman 2003). This resulted in an overview of different learning activities in the workplace that could also be applied to school leaders (see Table 1 for a brief description of the learning activities based on these well-known core studies). These activities served as the starting point for investigating learning experiences of school leaders. Several learning activities that we found in the literature on teacher professional development were not suitable for school leaders, such as "trying out something new in the classroom" or "receiving pupils' feedback". These activities were either left out of the overview for school leaders or adjusted in order to fit school leaders' workplace learning.

\section{Work-Related Questions that Incite Workplace Learning}

In our study workplace learning is conceived as an on-going process of embedded learning activities. The question arises what triggers school leaders to initiate or participate in a learning activity? Most learning in the workplace occurs while pursuing working rather than learning goals (Rausch 2013; Van de Wiel and Van den Bossche 2013). When workers encounter a problem, a desire arises to solve it. Learning, for example gaining new knowledge or developing new skills, can help find a solution to these work-related problems. Therefore this study aims to understand work-related questions that entice school leaders to learn. We define work-related questions as the content that incites a learning activity, such as a problem the school leader wishes to solve or a question he or she wants to find answers to.

Table 1 Learning activities of school leaders, based on core studies

Incidental workplace learning

- Cooperation with colleagues: can occur through sharing ideas or joint work.

- Working on improvements or innovations in the school.

- Doing research: in order to better understand a practical problem, a practice-based research may be helpful.

- Experimenting with new ways of working: trying out something new in the school.

- Reading the newspaper: as a way of "keeping up-to-date".

- Working on a practical problem in the school: working on practical problems that require immediate attention.

- Conversation with a teacher by the coffee machine, which may lead to new insights or other types of learning outcomes.

Non-formal workplace learning

- Self-reflection: stepping back from an experience and analysing the meaning to the self.

- Reflecting with colleagues: "self-reflection" in conversation with colleagues.

- Participating in a learning network.

- Role model / mentor: a specific form of reflection with a colleague who has a higher degree of experience.

- Asking / receiving feedback: a specific form of reflection with colleagues, in which a colleague gives his or her reaction to specific behaviour of the school leader in a specific situation.

- Visiting another school: as a way of gaining new insights into how colleagues from other schools operate.

- Reading subject matter literature: a form of "keeping up-to-date", yet often with higher intentionality than reading the newspaper.

- Community of practice: similar to a learning network, yet with a stronger relational tie among its members. 


\section{Learning Outcomes of Workplace Learning}

Now that we have defined the process and triggers (presage) of workplace learning in this study, next the question arises as to which kind of learning outcomes does workplace learning lead? First of all, we study individual learning outcomes of the school leaders. Secondly, this study incorporates specific improvements and innovations in the school, to which school leaders' workplace learning may lead.

\section{Individual Learning Outcomes}

Individual learning outcomes refer to competencies that school leaders may achieve and develop through workplace learning. Two perspectives on the concept of competence can be distinguished (Bound and Lin 2013). The first perspective views competence as an individual attribute that can be divided into subcategories, such as knowledge and skills. The advantage of such an approach is that it can capture specific forms of individual competence. The second, social-constructivist approach defines competence as improved understanding of one's (work) environment and a greater ability to interact in it. The latter approach is holistic in that it relates competence to contextual factors. On the other hand, the individual approach can be seen as a component of the holistic approach (Bound and Lin 2013; Van der Heijden 2000) and therefore it is an appropriate starting point to measure school leaders' competence development.

An often-used conceptualisation of competence that is rooted in the individual approach is that of professional expertise by Van der Heijden (2000). This conceptualisation has also been used as a research instrument in recent studies of professional development (Evers et al. 2011a, b; Heerkens et al. 2011; Njoku et al. 2010). Van der Heijden (2000) distinguishes between five generic dimensions of professional expertise, which can be defined as follows, when applied to school leaders:

1) Knowledge dimension refers to different types of knowledge that are needed in the school leadership profession, such as declarative knowledge (knowing that), procedural knowledge (knowing how) and conditional knowledge (knowing when and where and under what conditions).

2) Meta-cognitive knowledge means "knowing about knowing and knowing that one knows" (Van der Heijden 2000, p. 11).

3) Skills constitute the visible behaviour that is needed to perform certain tasks in the job of school leaders, such as good conversational techniques or methods for specific terrains (finance, personnel, etc.).

4) Social recognition refers to the degree knowledgeable colleagues in the organisation recognise the school leader as an expert.

5) Growth and flexibility means school leaders show the ability to learn and acquire learning outcomes in adjacent or completely new fields.

Van der Heijden (2000) defines these dimensions of professional expertise in a generic way, in order to capture levels of expertise in a wide variety of professions. Since workplace learning often has no clear, predetermined learning objectives, the generic formulation of the dimensions make them suitable for our study. We used the dimensions to categorise qualitative interview data. 


\section{School Outcomes: Improvements and Innovations}

In addition to individual learning outcomes, workplace learning of school leaders may also lead to outcomes in terms of improvements and innovations in the school. For example, in her 3-P model, Tynjälä (2013) describes that creative solutions, organisational development and improved quality can be seen as the product of workplace learning. Kessels (2001) differentiates between gradual improvements and radical innovations as a product of learning. Gradual improvement means elaborating on what is already present and may lead to refinement and specialisation (Verdonschot 2009). Radical innovation means radically breaking with the past and creating new opportunities. Individual learning outcomes and school outcomes will presumably be interrelated. For example, if a school leader's conversational skills improve, he may be better able to stimulate teachers to get along in a process of school improvement.

Now that we have discussed possible learning outcomes, we will discuss individual conditions and supportive characteristics of workplace learning that may facilitate school leaders to achieve these outcomes. We differentiate between the school leaders' experience of autonomy, competence and relatedness (Deci and Ryan 2000) during workplace learning as individual conditions, and peace and stability and creative turmoil (Kessels 2001) as supportive characteristics of the learning activity. The reason we have chosen for these conditions is the following. School leaders in (Dutch) secondary schools enjoy a high degree of autonomy in their work. A direct supervisor - that could provide valuable guidance during workplace learning (Billett 2002) - is absent. Furthermore, as a result of their subordinate role, teachers will often be reluctant to provide feedback to their school leader. Therefore workplace learning of school leaders will be highly dependent on their own initiative and proactivity. School leaders will probably best be able to proactively shape their workplace learning if they are intrinsically motivated to learn (Mankin 2009). We incorporated three basic psychological needs as individual conditions that support intrinsic motivation, namely autonomy, competence and relatedness (Deci and Ryan 2000). Secondly, characteristics of the learning environment are also crucial to facilitate workplace learning (Tynjälä 2008, 2013; Kessels 2001; Evers 2012). According to Kessels (2001) a work environment that is characterised by creative turmoil is necessary because it ignites workers to develop new skills and generate new ideas. Yet, creative turmoil must be balanced by a certain degree of peace and stability, in order to further integrate previously acquired abilities. We included creative turmoil and peace and stability as supportive characteristics of the learning activity. The next two paragraphs describe these conditions and characteristics in more detail.

\section{Individual Conditions: Autonomy, Competence and Relatedness}

Incidental and non-formal workplace learning is probably best supported if school leaders are intrinsically motivated to participate (Mankin 2009). Intrinsic motivation means that human beings are naturally inclined to engage in activities they find interesting, without the need for external pressure or reward (Gagné and Deci 2005). 
Deci and Ryan's (2000) self-determination theory describes how intrinsic motivation is supported through the satisfaction of three basic psychological needs:

- Autonomy. Autonomy has to do with free will. School leaders will feel autonomous during workplace learning if they experience control over the content and form of their learning activities.

- Competence refers to a person's ability to interact effectively with the environment and to achieve valued outcomes. It is the personal desire of school leaders to develop and get better at a certain task or activity.

This concept differs fundamentally from professional expertise as described earlier. Professional expertise refers to a person's level of performance as a learning outcome, whereas competence as a basic psychological need refers to an intrinsic desire to develop as a condition for workplace learning.

- Relatedness is the need to build sustainable and positive relationships with significant others during workplace learning.

This study examines school leaders' experience of these basic psychological needs during workplace learning and how they facilitate school leaders to achieve learning outcomes.

\section{Characteristics of the Learning Activity: Peace and Stability and Creative Turmoil}

According to Kessels (2001) two specifically valuable components of a work environment are "peace and stability" and "creative turmoil". We believe these are important in the context of school leaders' workplace learning as they trigger adventure, experimentation and radical innovation (creative turmoil), and enable reflection, coherence, synergy and gradual improvement (peace and stability).

Creative turmoil incites creativity and stimulates taking new paths. A certain degree of existential threat and the feeling of "all or nothing" often accompany creative turmoil. An example of creative turmoil in the context of education is the threat of closure due to poor student results.

Peace and stability on the other hand, are necessary to specialise and further integrate previously acquired abilities. It means there is ample possibility to reflect within a well-known domain. For facilitating workplace learning of school leaders it seems vital to create moments of peace.

Based on the theoretical building blocks described above, this leads to the research model in Fig. 1.

\section{Method}

The research method presented in this section was tailored to study in detail workplace learning of school leaders. Such a practice-based research method was necessary since little is known about school leaders' workplace learning. If adjustments are made, the method can be used to study workplace learning of leaders in different professions, as discussed in the concluding section of this article. 


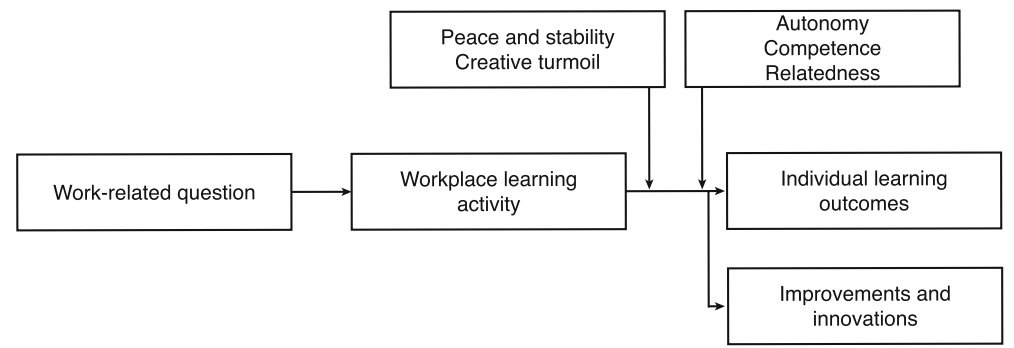

Fig. 1 School leaders' workplace learning

\section{Participants}

Large Dutch secondary school organisations often show several managerial layers. In order to demarcate the field of study, a clear definition of the school leader was necessary. The target group of this study consisted of “... officials $[\ldots]$ in secondary education who carry an integral responsibility for (a part of) the educational program" (Waslander et al. 2012, p. 9). In other words, the study focused on school leaders at the level of the entire school or large parts of the school. Administrators who transcend the school, or coordinators and team leaders of smaller units were not part of the sample. A total of 20 respondents were interviewed. Table 2 presents an overview of the demographic data of the respondents.

\section{Instruments}

Semi-structured interviews were conducted with 20 school leaders in secondary education. The semi-structured nature of the interview provided the opportunity to cover the theoretical concepts and also to dive deeper into answers of individual respondents (Bryman 2012). The questions in the interview guide were developed based on the main theories in our study (see theoretical framework). The interview guide consisted of the following components: 1) demographic data of the respondent, such as gender,

Table 2 Demographic data about respondents

Total number of respondents

Male / female

From region

North / middle / South

Age:

Average / lowest / highest

Employment years in education:

Average / lowest / highest

Employment years as school leader:

Average / lowest / highest

Education level:

Academic

Higher vocational

\section{0}


age, school, years of experience, and educational background, 2) compiling a top-3 of most valuable workplace learning activities, 3) exploration of respondent's number 1 learning activity in terms of work-related question, learning outcomes and facilitating conditions, and 4) closure: the respondents were asked if they wished to add anything to their previous answers.

The interview guide was set up such that it not only delivered valuable research data, but also served as a practice-based research intervention for school leaders' own learning. Workplace learning, especially incidental and non-formal workplace learning, is unorganised. Therefore, school leaders are often not aware of what they achieve through these activities and what supports their learning. The interview provided opportunity for the school leaders to reflect on learning outcomes and conditions of specific workplace learning activities. The semistructured set up, with open-ended questions for each of the theoretical building blocks, ensured both structure and space for individual experiences. Many respondents reported back that the summary of the interviews, which was sent afterwards, also served as a rich learning experience.

In addition to the interviews a total of 33 school leaders were also asked to compile a top-3, which resulted in an additional 33 top-3's of learning activities.

\section{Procedure}

Respondents (the 20 school leaders who were interviewed and the 33 school leaders who were asked to compile a top-3) were approached through a call on the website of the secondary education council, the employers association of secondary education in the Netherlands. Since the secondary education council represents over 600 of a total number of 652 secondary schools in the Netherlands (Secondary education council 2013), this provided access to a representative sample of Dutch school leaders. In order to guarantee a good representation, respondents were chosen from all three Dutch school regions (north, middle, south). Prior to the interview an email was sent to the respondents with an overview of workplace learning activities that came up in studying the literature (see Table 1). In the rare event if a specific learning activity was unclear to the respondent, the researcher gave additional explanation. The overview also offered the opportunity to add a learning activity from the respondent's own experience. At the start of the interview the respondents were asked to compile a top-3 list of learning activities they had experienced in the last year and found most valuable. The remainder of the interview focused on workrelated questions, learning outcomes and conditions of the respondent's number 1 learning activity. These concepts were investigated through open-ended questions. During the interview the researcher immediately transcribed all answers in an interview report. Furthermore, the interview was recorded in order to complement the report afterwards. Interview reports were sent to the respondent for approval, as a form of member check.

\section{Analysis}

Data analysis consisted of two steps: 1) ranking top-3's in first analysis, 2) using matrix coding for within-case and cross-case analysis (Miles et al. 2014). 


\section{Ranking the top-3's}

In the first step of data analysis all 53 top-3 lists of learning activities were ranked (20 from interviews and the additional 33 top-3's). A simple scoring system was used. Each time a learning activity was placed on number 1 , it received 3 points, each number 2 nomination led to 2 points and numbers 3 led to 1 point. Based on the ten highest ranked learning activities categories of workplace learning activities were established and used to analyse the data from 20 interviews (see the results below).

\section{Within- and Cross-Case Analysis: Conceptually Clustered Matrix}

For analysing the interview data both within- and cross-case, conceptually clustered matrices (Miles et al. 2014) were developed that systematically displayed data from all respondents. As this study aimed to better understand the nature of workplace learning of school leaders and study relationships between different concepts, conceptually clustered matrices suited this objective very well (Miles et al. 2014). Rows in the matrix represented the cases (school leaders) and columns represented the different theoretical concepts: workplace learning activity, work-related question, learning outcomes (2 types), conditions and characteristics. For learning outcomes, conditions and characteristics an extra column was added for "additional" findings. These columns referred to learning outcomes, conditions and characteristics that could not be categorised elsewhere. In addition to the matrix a codebook was developed to label interview data more specifically. Next, coded interview passages were placed in the cells of the matrix, under the associated theoretical concept. For example: a respondent's statement could be classified as an individual learning outcome in terms of "knowledge". This interview passage was then coded as "knowledge" and added to the cell under "individual learning outcomes".

Cross-case analysis was conducted deductively and inductively. This made it possible to study the theoretical concepts, and find additional concepts during data analysis (Miles et al. 2014). During early analysis it became clear that an extra concept could be added to the initial matrix. Respondents who learn through "working on improvement or innovation in the school" roughly choose two different approaches to shape the improvement- or innovation process. Therefore a column "change approach" was added to the matrix, and two codes were added to the codebook for both approaches, namely "planned" and "emergent".

\section{Validity and Reliability}

To ensure validity and reliability of the research findings, several measures have been taken. First of all, interviews were recorded and transcribed in a report. Interview reports were presented to the respondent for approval as a form of member check. Secondly, a group of three researchers was asked to verify the steps in data analysis as a form of peer examination. During these peer meetings specific attention was given to the new concept "change approach" that emerged during data analysis. Furthermore, an external researcher was asked to code $10 \%$ of our data set. His labels were compared to that of the first author. In order to measure inter-rater reliability, the Krippendorff's alpha was calculated. This resulted in an alpha of .821, where .800 is generally accepted as reliable (Krippendorff 2004). Where the first author and external rater differed, they discussed until they reached consensus, and 
codes were changed accordingly. Finally, the first author re-examined the codes used in the remainder of the data set, consulting the external researcher in case of doubt.

\section{Results}

\section{Workplace Learning Activities of School Leaders: Ranking the top-3's}

The first research question is aimed at specific learning activities in the workplace of school leaders that they consider valuable. Table 3 shows the ranking of the ten most valued learning activities in the workplace for school leaders, based on top-3's that were compiled by 53 school leaders. The right hand column shows the number of points each learning activity received and - in parentheses - the number of times it was put in first place.

The ranking shows that school leaders highly value learning in the workplace while they work on improvements or innovations in the school and through reflecting with colleagues. These learning activities received twice as many points as number 3 and over $40 \%$ of the total number of points. Furthermore, the other learning activities in this ranking are closely related to school improvement and innovation (working on a practical issue in the school) and reflection (participating in a learning network, self-reflection, asking for feedback, role model or mentor, and reflection in general). Cooperation with colleagues and visiting another school may involve both practical and reflective components, and therefore can be classified either as improvement and innovation or reflection.

Based on this ranking we have created three categories of workplace learning activities for secondary school leaders. The second category - reflection - is divided into three subcategories that differ in the people that are involved and the degree to which the reflection is formalised.

1) Working on improvement and innovation in the school. A school leader that works on improvement or innovation will not necessarily have the intention to learn. It

Table 3 Ranking of workplace learning activities

\begin{tabular}{lll}
\hline No. & Workplace learning activity & Pts. (times at no. 1) \\
\hline 1. & Working on improvements or innovations in the school & $53(11)$ \\
2. & Reflecting with colleagues & $53(10)$ \\
3. & Participating in a learning network & $26(2)$ \\
4. & Cooperation with colleagues & $25(6)$ \\
5. & Visiting another school & $21(3)$ \\
6. & Self-reflection & $20(2)$ \\
7. & Asking / receiving feedback & $18(4)$ \\
8. & Role model / mentor & $15(3)$ \\
9. & Reflecting in general & $11(2)$ \\
10. & Working on a practical problem in the school & $10(1)$ \\
Total & & 252 \\
\hline
\end{tabular}


can "simply" be aimed at solving a problem in the school. Yet, in retrospect during the interviews, most respondents labelled this activity as their most valuable learning activity. A main characteristic of this learning activity is that it generates incidental learning.

2) Reflection is an activity in which the school leader is stepping back from an experience to analyse the meaning to the self. Respondents in our study reflect in three different ways:

a. Unorganised reflection takes place intentionally, but unorganised. This category comprises self-reflection but also reflection with colleagues in the workplace, for example spontaneously after a working project. There is often an intention to learn and therefore these learning activities can be labelled non-formal.

b. Organised reflection with colleagues at the workplace. Reflection with colleagues can also be intentional and - to a certain degree - organised at the workplace, such as deliberately asking feedback from teachers after a team meeting. These activities are non-formal by nature. Colleagues with whom the school leader reflects can be fellow school leaders and in rare cases - teachers.

b. Externally organised reflection with colleagues. This third category of reflection with colleagues is also intentional, but organised outside of the school. Examples are non-formal activities, such as a learning network. This reflection can also be organised more formally, for example after role-playing in leadership training. Activities in this category are more organised than the second category. In this type of reflection, the school leader often reflects with fellow school leaders from other schools.

3) Other learning activities: all workplace learning activities that cannot be categorised elsewhere.

We can conclude that the main difference between the first and second category is the degree of intentionality to learn. In general intentional reflection will not take place when working on improvement and innovation in the school, yet it can occur afterwards. Hence, we consider these categories as different learning activities.

Since these categories were also evident in the learning activities that were put in first place by the 20 respondents, we used them to structure the interview data. Table 4 shows the specific learning activities that the 20 interviewees put in first place, divided over these three categories.

In the following paragraphs we will describe work-related questions, individual learning outcomes, school outcomes, individual conditions and characteristics of the learning activity for each of these three categories. If necessary, relevant quotes of respondents illustrate the results. In order to guarantee anonymity, names have been changed.

\section{Working on Improvement and Innovation in the School}

Eight school leaders nominated working on improvement and innovation as their most valuable learning activity. First we describe the approaches school 
Table 4 Specific learning activities of 20 interviewees, divided by category

1) Working on improvement and innovation in the school (8 respondents)

2) Reflection

a. Unorganised reflection

(4 respondents)

- Reflection with fellow school leader

- Self-reflection $(2 \times)$

- Reflecting in general: both self-reflection and with colleagues

b. Organised reflection with colleagues at the workplace

(3 respondents)

- Asking for feedback from teachers after team meetings $(2 \times)$

- Role mode / mentor

c. Externally organised reflection with colleagues

(3 respondents)

- Participating in a learning network

- Regional consultation body

- Feedback after role-playing during leadership training

3) Other learning activities

(2 respondents)

- Training teachers from other schools

- Experience during meeting with board

leaders used to shape these processes, a concept that emerged during data analysis.

\section{Approaches}

Respondents reported two different approaches to improvement and innovation, which we termed "planned" and "emergent". Three out of eight school leaders" approaches were planned. The main characteristic of the planned approach is that improvement starts with determining a clear and measurable desired end result. Additionally, a thorough diagnosis of existing problems is carried out. For example, David describes how he analysed all aspects in his school (i.a. his own leadership role, behaviour of employees, primary process) before working on an improvement. Next a tight plan of action is determined. The school leader may appoint a project group to reach the end result and makes sure the group sticks to the plan.

Four out of eight school leaders on the other hand, worked emergently (for one school leader the approach was unclear). They do not exactly set the results in advance. Rather, they encourage employees to experiment with new ideas. Frank, for example, emphasized the importance of a clear vision in an emergent approach. His vision can be seen as the cadre for teachers to work out ideas:

I have a strong vision. [...]. I also share that vision. [...]. If an idea fits within the plan, it's possible.

Using a planned approach means the process is largely set in advance, with little room to deviate from the original plan. The school leader keeps a close 
watch on the execution of the plan. Emergent school leaders share a vision and encourage teachers to experiment and take initiative within that vision.

\section{Work-Related Questions that Incite Improvement and Innovation}

Three out of eight school leaders reported work-related questions of improvement and innovation that need to be solved immediately. These questions often originate from external parties. An example is Wesley's school which was about to be shut down by the inspectorate due to a lack of proper organisation. The other five respondents describe work-related questions that do not necessarily need to be solved straight away, but originate from their personal ambition. An example is Hank, who wishes to equip his teachers so that they support pupils' self-regulated learning.

Our data show no relationship between this nature of the work-related question and the chosen approach.

\section{Individual Learning Outcomes of Improvement and Innovation}

School leaders reported different individual learning outcomes depending on the approach (planned or emergent). School leaders who use a planned approach learn to apply the planned approach better, whereas those using an emergent approach grow in facilitating teachers to work on improvement. For example, Wesley uses a planned approach and explains that his skills have grown in confronting employees and making them aware of their responsibilities. Three out of four school leaders who used the emergent approach also report improved skills and acquired knowledge. Yet unlike Wesley - who has learned confrontation skills - these school leaders reported skills and knowledge to support and motivate teachers to get along in the process, such as careful listening to teachers and being informed about their desires and ambitions. These learning outcomes contrast strongly with school leader Hank, who used a planned approach, but had trouble motivating his teachers to get along in the change process. He says he has learned to understand that a positive attitude of teachers towards the innovation process, does not necessarily lead to changed behaviour (knowledge).

\section{School Outcomes of Improvement and Innovation}

As expected, working on improvement and innovation leads to specific school outcomes, for example improved student results, enhanced homework supervision and new ways of working during team meetings. Analysis of the school outcomes revealed a difference between the improvements and innovations that were realised in a planned fashion and those that were realised emergently. The school outcomes of planned approaches were fully in line with the desired end result. Hence, they were expected at the start of the process. The school outcomes from emergent approaches were unforeseen. In some cases improvements were even realised in completely different terrains. For example in Alfred's school, the original plan was to support students in self-directing their learning. During the process, the school's team meetings were also adjusted in order to create more space for self-direction of teachers. 


\section{Additional Learning Outcomes of Improvement and Innovation}

Planned school leaders Wesley and David both reported that their planned approach is taken over by teachers. These are examples of workplace learning of school leaders who believe it leads to additional learning outcomes for teachers.

School leaders who work emergently also reported additional learning outcomes of teachers. Yet where Wesley and David reported that teachers follow their example in applying a planned approach, emergent school leaders describe more unexpected learning outcomes for teachers, such as an unforeseen change in teachers' attitude towards students.

\section{Individual Conditions in Improvement and Innovation}

Some individual conditions of improvement and innovation facilitated school leaders to achieve learning outcomes. One school leader describes how the results he realises during a process of improvement and innovation are a direct form of feedback on the way he operates. Whether he is doing well or poorly will be reflected in the results. This satisfies his need for competence. Another school leader describes that in processes of improvement and innovation often many colleagues are involved, which satisfies his need for relatedness.

Yet the most notable aspects of improvement and innovation that facilitate learning outcomes lie in the characteristics of this learning activity.

\section{Characteristics of Improvement and Innovation: Peace and Stability and Creative Turmoil}

In specific work-related questions that incite improvement and innovation, three school leaders reported examples of creative turmoil as the driving force behind their learning. These school leaders all have work-related questions that originate from an external party (such as the inspectorate) and require immediate attention. This creative turmoil fuels their learning, as is described by Wesley:

If I don't do it, nobody will. You are being forced. [...]. That pressure is on the one hand a heavy burden. On the other hand it is a great motivator.

David also encounters a problem that he needs to solve quickly (poor student results). Rather than using this creative turmoil to facilitate his learning - as does Wesley - he carries out a thorough research of existing problems to help him convince his board to be patient, and have faith in his plan for improving the situation. Hereby he is able to maintain peace and stability in the school.

The other five school leaders do not have a problem that needs to be solved immediately and therefore external creative turmoil is lacking. Yet they do seem to feel or create a sense of creative turmoil in order to stay motivated and motivate others. Hank for example wants teachers to adopt strategies for supporting self-regulated learning of students. He emphasized that not solving this problem will on the long run lead to disastrous consequences for both pupils and teachers. 


\section{Reflection}

In total ten respondents mentioned reflection as a learning activity (see also Table 4).

\section{Work-Related Questions that Incite Reflection}

Six out of ten respondents (in all subcategories of reflection) reported questions that relate to communication with teachers. During these matters school leaders often find themselves confronted with dilemma's, such as on the one hand telling a teacher he is not qualified to become team leader and on the other hand appreciate the teacher for his teaching abilities.

Two respondents who organised reflection at the workplace reflect on keeping up a good working relationship with their team. The work-related questions discussed during the two remaining externally organised reflection activities (learning network and consultation body) are less directly related to a specific practical problem. Rather they start from a shared interest in a specific theme, for example "leadership" or "learning".

\section{Individual Learning Outcomes of Reflection}

All learning outcomes that school leaders reported from reflection are individual learning outcomes. Nearly all school leaders who learn through reflection (7 out of 10) reported examples of meta-cognitive knowledge as a learning outcome, such as the realisation of missing knowledge or skills to realise certain ambitions.

Additionally, the six school leaders who reflect on interaction and communication with teachers mainly reported improved conversational skills as a learning outcome. These conversational skills often go hand in hand with gained knowledge on conversational matters (such as the realisation to involve teachers in decision-making processes) and meta-cognitive knowledge about the school leader's own role (for example an awareness of the impact of one's actions). The two school leaders who organise reflection at the workplace (through asking for feedback from teachers after team meetings) both explained how they, more than before, share relevant information with teachers and involve teachers more explicitly in their work. Although they did not report specific learning outcomes for teachers as a result, for one school leader it does lead to social recognition in terms of appreciation from teachers.

\section{School Outcomes and Additional Learning Outcomes of Reflection}

For reflection, we did not find school outcomes in terms of improvements and innovations or any other additional learning outcomes.

\section{Individual Conditions of Reflection}

Five school leaders (in all three types of reflection) described relatedness as a facilitating condition for reflection. Alma, who reflects with a fellow school leader from her school, explains that reflecting with this colleague is "comfortable", because it can sometimes be "lonely at the top". Externally organised reflection, for example during a learning network, gives the pleasant opportunity to meet and get inspired by colleagues from other schools. 
Four school leaders described how reflection offers ample opportunity to improve certain skills or behaviour, which is an example of the satisfaction of competence. Furthermore, two school leaders describe the possibility to formulate their own learning question as an important condition for reflection (autonomy).

\section{Characteristics of Reflection: Peace and Stability}

A frequently mentioned characteristic of reflection is peace and stability (three cases). This is the case during externally organised reflection and unorganised reflection in the shape of self-reflection, and best described by Jim:

If I keep 'running', and never take time to stand still to think why I do things the way I do them, I will never become a good school leader.

The work environment of these school leaders is often characterised by disquiet, and reflection at a location external to the school provides necessary space for peace and stability. In short, in contrast with working on improvement and innovation - that are often dynamic processes with creative turmoil - reflection is characterised by the possibility to relate to fellow school leaders and peace and stability.

\section{Other Learning Activities}

Two school leaders nominated learning activities that we have categorised as "other": Anna said she learned through training teachers from other schools and Alex nominated a recent meeting with his board as most valuable. Anna's work-related question was that she wanted to become school leader at the time she was still a teacher. This was an opportunity for her to network. Her learning outcomes through training teachers from other schools were knowledge and skills that helped her discuss sensitive matters with teachers in her own school. Her learning is mainly facilitated through her work with another trainer (relatedness). Alex said he hates it when his board thinks and talks in "blueprints" and tries to control and regulate everything in his school. When this happens, his work-related question is that he wants to be able to express his opinion in a constructive way. His main learning outcome is the realisation that he expresses non-verbally how he feels about this matter, which is not helpful (knowledge). No facilitating condition could be found with Alex's learning activity.

\section{Conclusions and Discussion}

Two main research questions guided this study: 1) what learning activities in the workplace do school leaders in secondary education value most, and 2) what are work-related questions, facilitating conditions and characteristics, and learning outcomes of these workplace learning activities?

Our findings show that Dutch secondary school leaders mainly value learning in the workplace through working on improvements and innovations in the school and through reflection. The findings show that school leaders choose two different approaches for improvement and innovation, a planned and an emergent approach, which have also been 
described by several other authors (Sprenger and Teeuwisse 2011; Thorpe et al. 2011). Following a planned approach means the process is largely set in advance, with clearly determined end results and a tight plan of action. In contrast, the emergent approach leaves room for experimentation by teachers. The school leaders work from a clear vision that serves as a framework and reference for teachers to develop ideas further. According to Sprenger and Teeuwisse (2011), choosing the appropriate approach is dependent on the nature of a work-related question. Relatively simple and predictable problems benefit from a planned approach, whereas complex problems require an emergent approach. In contrast with this expectation, our data show no clear connection between the nature of a work-related question and the chosen approach. Possibly the personal preference of the school leader plays a more important role in choosing an approach. When school leaders reflect on work experiences, they either participate in externally organised reflection, organise reflection at the workplace or spontaneously reflect in the workplace unorganised.

These two main categories of school leaders' workplace learning differ in workrelated questions, learning outcomes and supportive conditions and characteristics.

Work-related questions that entice working on improvement and innovation can either stem from external demands or from the school leaders' personal ambitions. Examples of external demands are pressure from the inspectorate to improve student results or renew school management. Ambitions closely relate to what school leaders personally find relevant.

Working on improvement and innovation often involves teachers in long-term projects, which not only leads to individual learning outcomes for secondary school leaders, but also to additional learning outcomes for teachers. Furthermore, as expected these learning activities lead to school outcomes in terms of improvements and innovations. Our data show fundamental differences between learning outcomes from a planned approach and an emergent approach to improvement and innovation. The first difference lies in the individual learning outcomes. Those using a planned approach often report improved skills to apply the planned approach and motivate teachers to adopt the approach as well. Those using the emergent approach learn skills to facilitate and support teachers. Moreover, the emergent approach leads to unexpected school outcomes and learning outcomes of teachers, such as unforeseen innovations and initiatives of teachers. The planned approach on the other hand leads to more expected outcomes, such as teachers who - following the example of the school leader - adopt the planned approach themselves. Hence, it seems that in the planned approach teachers will follow the school leader's example and school outcomes will be realised in line with the school leader's wishes. Yet, if a school leader learns to facilitate and support teachers to try out new things, teachers learn in unexpected areas and unforeseen school outcomes are realised.

Although external pressure during improvement and innovation can be stressful, the right amount of creative turmoil seems to work as a strong characteristic that supports workplace learning. Given their unique autonomous position within the school, secondary school leaders can impose creative turmoil on themselves, when improvement or innovation starts from their own personal ambition. It seems that many school leaders thrive in situations of creative turmoil, but some prefer calm and peace. These findings show that school leaders can influence the amount of peace and stability and creative turmoil in their school, and subsequently regulate a balance between the two. 
During reflection, work-related questions often involve communication and interaction with teachers. Here dilemmas play an important role, as was also shown by De Wit (2012).

During all types of reflection, we only found individual learning outcomes for school leaders, mainly in terms of meta-cognitive knowledge. This is not surprising since reflection involves "... stepping back from an experience to ponder, carefully and persistently, its meaning to the self...” (Daudelin 1996, p. 39).

While during processes of improvement and innovation creative turmoil is the main driver for workplace learning, reflection especially offers peace and stability and relatedness with other secondary school leaders. Peace and stability can be created at the workplace through reflecting privately with a fellow school leader. It is interesting though, that peace and stability seems easily created outside of the school, for example during learning networks with fellow school leaders from other schools. This indicates that secondary school leaders experience a lack of peace and stability in their school.

To conclude, our study shows that Dutch secondary school leaders mainly value two types of workplace learning. In workplace learning through working on improvement and innovation, teachers are clearly involved. Yet there is a difference between their role in an emergent approach - where they have ample room to experiment and take initiative - and a planned approach - where the process is set in advance and teachers mainly follow school leaders' demands. During reflection of school leaders on the other hand, teachers play no noteworthy part. In light of Michael Fullan's (2014) argument that one of the school leaders' main roles is to lead learning through learning alongside teachers, excluding teachers from workplace learning can be harmful for a fruitful learning environment in the school, and eventually for student results. These findings are even more meaningful given the recent interest in distributed leadership in schools. Distributed leadership postulates that leadership is not solely reserved for the school leader, but can be claimed depending on the situation and the expertise required (DeRue and Ashford 2010; Kessels 2012; Spillane 2006). Each teacher possesses relevant expertise that may be needed at a given time (Harris 2008). Kessels (2012) argues that distributed leadership in schools is vital for teacher professional development. School leaders can be seen as the "gatekeepers" who should create fruitful conditions for distributed leadership to flourish (Harris 2008). The way school leaders organise reflection at the workplace in this study does not provide the opportunity for teachers to influence change. Although the planned approach for innovation does offer space to take initiative, this mostly involves following school leaders' assignments. The emergent approach towards improvement and innovation seems to offer the best environment for teachers to take initiative on the basis of their specific expertise and interests, and subsequently to learn alongside their school leader. This was also shown in a recent and related study in corporate contexts (Sijbom 2013).

Our theoretical framework was built up similar to Tynjälä's (2013) 3-P model, incorporating presage, process and product components of workplace learning. On the "product" side of the 3-P model, Tynjälä differentiates mainly between individual learning outcomes (e.g., academic knowledge), and improvements and innovations. Based on the secondary school leaders' data in our study, during certain school leaders' workplace learning activities, teachers also participate and realise learning outcomes as discussed in the previous section. Therefore, we suggest adding "collective learning outcomes" as a possible product of workplace learning to the 3-P model. 


\section{Future Research and Limitations of this Study}

The methods used in our study could be modified to explore workplace learning of leaders in similar "frontline professions" (Bruining 2006), such as health care and police. An important practice-based feature of our research design is the interview guide, which served as a useful intervention instrument, facilitating a rich form of reflection for the respondents. The concepts used and found in this study can be the starting point for instrument development aimed at other contexts. Another main feature of our design is that it incorporates different theoretical concepts linked to the 3-P model of workplace learning (Tynjälä 2013), while leaving room for finding new concepts bottom up. Therefore the overall design of the study is transferable to similar contexts. Yet, additional literature search into specific learning activities in other contexts is needed and instruments must be adjusted accordingly. Finally, it is worthwhile to elaborate on the possible connection between different forms of school leaders' workplace learning, and possibilities for teachers to learn as well and take leadership within the school.

This study has several limitations. Firstly, respondents' reports of prior experiences can be biased (Rausch 2013). In order to minimise this bias, respondents were asked about experiences in the recent past. Nevertheless, this bias can be present and further research into workplace learning of school leaders that also incorporates others' perspectives, such as those of teachers, is worthwhile. Furthermore, since little is known about school leaders' workplace learning, we used a qualitative research design in order to generate in-depth insights from an insider's perspective. We consider this a necessary first step. Given that previous studies have shown discrepancies between what leaders say they value and what they actually practice during work (Argyris et al. 1985), additional research using observation and other sorts of (quantitative) data collection are an essential next step.

Open Access This article is distributed under the terms of the Creative Commons Attribution 4.0 International License (http://creativecommons.org/licenses/by/4.0/), which permits unrestricted use, distribution, and reproduction in any medium, provided you give appropriate credit to the original author(s) and the source, provide a link to the Creative Commons license, and indicate if changes were made.

\section{References}

Argyris, C., Putnam, R., \& McLain Smith, D. (1985). Action science: Concepts, methods, and skills for research and intervention. San Francisco: Jossey-Bass.

Avalos, B. (2011). Teacher professional development in teaching and teacher education over ten years. Teaching and Teacher Education, 27(1), 10-20. doi:10.1016/j.tate.2010.08.007.

Bakkenes, I., Vermunt, J. D., \& Wubbels, T. (2010). Teacher learning in the context of educational innovation: learning activities and learning outcomes of experienced teachers. Learning and Instruction, 20(6), 533548. doi:10.1016/j.learninstruc.2009.09.001.

Benson, P. (2010). Teacher education and teacher autonomy: creating spaces for experimentation in secondary school English language teaching. Language Teaching Research, 14(3), 259-275. doi:10.1177/ 1362168810365236.

Biggs, J. (1999). Teaching for quality learning at university. What the student does. Buckingham: Society for Research into Higher Education \& Open University Press.

Billett, S. (2002). Toward a workplace pedagogy: guidance, participation, and engagement. Adult Education Quarterly, 53(1), 27-43. doi:10.1177/074171302237202.

Billett, S. (2004). Learning through work: Workplace participatory practices. In H. Rainbird, A. Fuller, \& A. Munro (Eds.), Workplace learning in context (pp. 109-125). London: Routledge. 
Billett, S. (2009). Personal epistemologies, work and learning. Educational Research Review, 4(3), $210-219$. doi:10.1016/j.edurev.2009.06.001.

Bound, H., \& Lin, M. (2013). Developing competence at work. Vocations and Learning, 6(3), 403-420. doi: 10.1007/s12186-013-9102-8.

Branch, G. F., Hanushek, E. A., \& Rivkin, S. G. (2013). School leaders matter. Education Next, 13(1), 62-69.

Bruining, A. W. M. (2006). Learning behind the frontline of public service. Utrecht: University for Humanities.

Bryman, A. (2012). Social research methods (4th ed.). Oxford: Oxford University Press.

Darling-Hammond, L., Chung Wei, R., Andree, A., Richardson, N., \& Orphanos, S. (2009). Professional learning in the learning profession: a status report on teacher development in the United States and abroad. Stanford: National Staff Development Council.

Daudelin, M. W. (1996). Learning from experience through reflection. Organizational Dynamics, 24(3), 3648. doi:10.1016/S0090-2616(96)90004-2.

Day, C., Sammons, P., Hopkins, D., Harris, A., Leithwood, K., Gu, Q., Brown, E., Ahtaridou, E., \& Kington, A. (2009). The impact of school leadership on pupil outcomes. Final Report. Nottingham, UK: University of Nottingham/National College for School Leadership. doi:10.1007/BF02653588.

De Wit, B. C. (2012). Loyale leiders. Een onderzoek naar de loyaliteit van leidinggevenden aan docenten in het voortgezet onderwijs [Loyal leaders. A study into loyalty of school leaders in secondary education]. Utrecht: University of Utrecht.

Deci, E. L., \& Ryan, R. M. (2000). The "what" and "why" of goal pursuits: human needs and the selfdetermination of behavior. Psychological Inquiry: An International Journal for the Advancement of Psychological Theory, 11(4), 227-268. doi:10.1207/S15327965PLI1104 01.

DeRue, D. S., \& Ashford, S. J. (2010). Who will lead and who will follow? A social process of leadership identity construction in organizations. Academy of Management Review, 35(4), 627-647.

Dochy, F., Gijbels, D., Segers, M., \& Van den Bossche, P. (2011). Theories of learning for the workplace. Building blocks for training and professional development programs. London: Routledge.

Engeström, Y., Rantavuori, J., \& Kerosuo, H. (2013). Expansive learning in a library: actions, cycles and deviations from instructional intentions. Vocations and Learning, 6(1), 81-106. doi:10.1007/s12186-012-9089-6.

Evers, A. T. (2012). Teachers' professional development at work and occupational outcomes: An organisational and task perspective. Heerlen: Open University of the Netherlands.

Evers, A. T., Kreijns, K., Van der Heijden, B. I. J. M., \& Gerrichhauzen, J. T. G. (2011a). An organizational and task perspective model aimed at enhancing teachers' professional development and occupational expertise. Human Resource Development Review, 10(2), 151-179. doi:10.1177/1534484310397852.

Evers, A. T., Van der Heijden, B. I. J. M., Kreijns, K., \& Gerrichhauzen, J. T. G. (2011b). Organisational factors and teachers' professional development in Dutch secondary schools. Journal of European Industrial Training, 35(1), 24-44. doi:10.1108/03090591111095727.

Evers, A. T., Van der Heijden, B. I. J. M., Kreijns, K., \& Vermeulen, M. (2015). Job demands, job resources, and flexible competence: the mediating role of teachers' professional development at work. Journal of Career Development, 28, 2015. doi:10.1177/0894845315597473 published online before print July 28, 2015.

Fazio, X. (2009). Teacher development using group discussion and reflection. Reflective Practice: International and Multidisciplinary Perspectives, 10(4), 529-541. doi:10.1080/14623940903138407.

Fenwick, T. (2008a). Understanding relations of individual-collective learning in work: a review of research. Management Learning, 39(3), 227-243. doi:10.1177/1350507608090875.

Fenwick, T. (2008b). Workplace learning: emerging trends and new perspectives. Embroidery, 2008(119), 1726. doi:10.1002/ace.

Foundation, T. W. (2012a). The school principal as leader: Guiding schools to better teaching and learning. New York: The Wallace Foundation.

Foundation, T. W. (2012b). The making of the principal: Five lessons in leadership training. New York: The Wallace Foundation.

Fullan, M. (2014). The principal. Three keys to maximizing impact. San Francisco: Jossey-Bass.

Gagné, M., \& Deci, E. L. (2005). Self-determination theory and work motivation. Journal of Organizational Behavior, 26(4), 331-362. doi:10.1002/job.322.

Gurr, D. (2015). A model of successful school leadership from the international successful school principalship project. Societies, 5(1), 136-150. doi:10.3390/soc5010136.

Harris, A. (2008). Distributed school leadership. Developing tomorrow's leaders. Oxon/New York: Routledge.

Heerkens, H., Norde, C., \& Van der Heijden, B. I. J. M. (2011). Importance assessment of decision attributes: a qualitative study comparing experts and laypersons. Management Decision, 49(5), 748-761. doi:10.1108/ 00251741111130832.

Hulsbos, F. A., Evers, A. T., Kessels, J. W. M., \& De Laat, M. (2014). Een aantrekkelijke leeromgeving voor schoolleiders. Onderzoek naar het non- en informele leren van schoolleiders in het voortgezet onderwijs [A 
conducive learning environment for school leaders. Study into non- and informal learning of secondary school leaders]. Heerlen: Welten Institute. Research Centre for Learning, Teaching And Technology - Open University of the Netherlands.

Kessels, J. W. M. (2001). Verleiden tot kennisproductiviteit [Enticing knowledge productivity]. Enschede: University of Twente.

Kessels, J. W. M. (2012). Leiderschapspraktijken in een professionele ruimte [Leadership-practices in a professional space]. Heerlen: LOOK - Scientific Centre Teacher Research - Open University of the Netherlands.

Krippendorff, K. (2004). Reliability in content analysis. Some common misconceptions and recommendations. Human Communication Research, 30(3), 411-433. doi:10.1111/j.1468-2958.2004.tb00738.x.

Kwakman, K. (2003). Factors affecting teachers' participation in professional learning activities. Teaching and Teacher Education, 19(2), 149-170. doi:10.1016/S0742-051X(02)00101-4.

Mankin, D. (2009). Human resource development. Oxford: Oxford University Press.

Marsick, V. J., \& Watkins, K. E. (1990). Informal and incidental learning in the workplace. New York: Routledge.

Miles, M. B., Huberman, A. M., \& Saldana, J. (2014). Qualitative data analysis. A methods sourcebook (3rd ed.). Thousand Oaks: Sage Publications, Inc.

Njoku, J. C., Van der Heijden, B. I. J. M., \& Inanga, E. L. (2010). Fusion of expertise among accounting faculty: towards an expertise model for academia in accounting. Critical Perspectives on Accounting, 21(1), 51-62. doi:10.1016/j.cpa.2008.03.001.

Rausch, A. (2013). Task characteristics and learning potentials - empirical results of three diary studies on workplace learning. Vocations and Learning, 6(1), 55-79. doi:10.1007/s12186-012-9086-9.

Secondary Education Council. (2013). Jaarverslag 2013 [Annual report 2013]. Utrecht: VO-raad.

Sijbom, R. B. L. (2013). Leaders' reactions to employee creativity: An achievement goal approach. Groningen: University of Groningen.

Spillane, J. P. (2006). Distributed leadership. San Francisco: Jossey-Bass.

Sprenger, C., \& Teeuwisse, E. (2011). Slim vakmanschap. Onderzoek rond het versterken van vakmanschap binnen de politie [Smart craftsmanship. A study into enforcing craftsmanship within the police force]. Den Haag: Boom Lemma.

Thorpe, R., Gold, J., \& Lawler, J. (2011). Locating distributed leadership. International Journal of Management Reviews, 13(3), 239-250. doi:10.1111/j.1468-2370.2011.00303.x.

Tynjälä, P. (2008). Perspectives into learning at the workplace. Educational Research Review, 3(2), 130-154. doi:10.1016/j.edurev.2007.12.001.

Tynjälä, P. (2013). Toward a 3-P model of workplace learning: a literature review. Vocations and Learning, 6(1), 11-36. doi:10.1007/s12186-012-9091-z.

Van de Wiel, M. W. J., \& Van den Bossche, P. (2013). Deliberate practice in medicine: the motivation to engage in work-related learning and its contribution to expertise. Vocations and Learning, 6(1), 135-158. doi:10.1007/s12186-012-9085-x.

Van der Heijden, B. I. J. M. (2000). The development and psychometric evaluation of a multidimensional measurement instrument of professional expertise. High Ability Studies, 11(1), 9-39.

Verdonschot, S. G. M. (2009). Learning to innovate: A series of studies to explore and enable learning in innovation practices. Enschede: University of Twente. doi:10.3990/1.9789036528757.

Waslander, S., Dückers, M. L. A., \& Van Dijk, G. M. (2012). Professionalisering van schoolleiders in het voortgezet onderwijs. Een gedeeld referentiekader voor dialoog en verbetering [Professional development of school leaders in secondary education. A shared frame of reference for dialogue and improvement]. Utrecht: VO-raad.

Frank Hulsbos MSc is an external Ph.D. candidate at the Welten Institute of the Open University in the Netherlands. His research focuses on workplace learning of teachers and school leaders, and distributed leadership in schools.

Arnoud Evers Ph.D. is an Assistant Professor at the Welten Institute of the Open University in the Netherlands. His main research interests are teacher professional development from an organisational perspective. He published in among others Human Resource Development Review, Review of Educational Research and European Journal of Training and Development.

Prof. dr. Joseph Kessels is Professor "Educational Leadership" at the Welten Institute of the Open University in the Netherlands. His research focuses on among others the relationship between distributed leadership and teacher professional development. 